\title{
Effects of Ortho-Phosphate on Growth Performance, Welfare and Product Quality of Juvenile African Catfish (Clarias gariepinus)
}

\author{
Sebastian M. Strauch ${ }^{1, *(\mathbb{D})}$, Judith Bahr ${ }^{1}$, Björn Baßmann ${ }^{1}{ }^{1}$, Adrian A. Bischoff ${ }^{1}$, \\ Michael Oster ${ }^{2}$, Berit Wasenitz ${ }^{1}$ and Harry W. Palm ${ }^{1}$ (D) \\ 1 Professorship Aquaculture and Sea-Ranching, Faculty of Agricultural and Environmental Sciences, \\ University of Rostock, Justus-von-Liebig-Weg 6, 18059 Rostock, Germany; judith.bahr@web.de (J.B.); \\ Bjoern.bassmann@gmx.de (B.B.); Adrian.bischoff-lang@uni-rostock.de (A.A.B.); \\ Berit.wasenitz@uni-rostock.de (B.W.); harry.palm@uni-rostock.de (H.W.P.) \\ 2 Leibniz Institute for Farm Animal Biology (FBN), Wilhelm-Stahl-Allee 2, 18196 Dummerstorf, Germany; \\ oster@fbn-dummerstorf.de \\ * Correspondence: sebastian.strauch@uni-rostock.de
}

Received: 28 November 2018; Accepted: 14 January 2019; Published: 23 January 2019

\begin{abstract}
Ortho-phosphate inside recirculation aquaculture systems is limited as a consequence of precipitation and regular water exchange rates. To improve plant growth in coupled aquaponics, phosphate fertilizer addition to hydroponics can increase $\mathrm{PO}_{4}{ }^{3-}-\mathrm{P}$ concentrations inside the process water. We investigated the effects of four $\mathrm{PO}_{4}{ }^{3-}-\mathrm{P}$ concentrations ( $<10(\mathrm{P} 0), 40,80,120 \mathrm{mg} \mathrm{L}^{-1}$ ) in rearing water on growth performance, feed efficiency, and welfare traits of juvenile African catfish (Clarias gariepinus Burchell, 1822). By trend, optimum specific growth rate of $2.66 \% \mathrm{~d}^{-1}$ and feed conversion ratio of 0.71 were observed at 40 and $80 \mathrm{mg} \mathrm{L}^{-1} \mathrm{PO}_{4}{ }^{3-}-\mathrm{P}$. Higher $\mathrm{PO}_{4}{ }^{3-}{ }_{-} \mathrm{P}$ significantly affected skin coloration, swimming activity and external injuries, with the palest and inactive fish combined with most external injuries in the P120 group. Mineral and protein contents in the fish remained unaffected, while fat content inside the fillets enriched with increasing $\mathrm{PO}_{4}{ }^{3-}-\mathrm{P}$. Inorganic $\mathrm{P}$ in blood plasma increased significantly, while phosphate concentrations inside the fillet remained unchanged. We suggest that $\mathrm{PO}_{4}{ }^{3-}-\mathrm{P}$ concentrations of 40 to $80 \mathrm{mg} \mathrm{L}^{-1}$ do not reduce the performance of African catfish aquaculture, while increased values of $120 \mathrm{mg} \mathrm{L}^{-1}$ affect fish welfare. This allows limited addition of $\mathrm{PO}_{4}{ }^{3-}-\mathrm{P}$ fertilizer in coupled aquaponics with African catfish to support plant growth.
\end{abstract}

Keywords: African catfish (Clarias gariepinus); growth; feed efficiency; elevated phosphate concentrations; welfare

\section{Introduction}

Phosphorus contributes essentially to the growth of animals and plants, because it plays a key role in many vital components [1-3]. In aquaculture systems, fish satisfy their demand for $\mathrm{P}$ with their diet [4], while in hydroponic systems, inorganic fertilizer supplies $\mathrm{P}$ (as $\mathrm{PO}_{4}{ }^{3-}-\mathrm{P}$ ) to the plants $[5,6]$. In the combination of both, known as aquaponics, the plants will ideally satisfy their demand from unretained $P$ excreted by the fish $[7,8]$. However, recent evidence suggests that the levels of $\mathrm{P}$ originating from aquaculture process water are low due to rapid precipitation, limiting its use for an optimal plant growth [9-11]. In decoupled aquaponic systems, this deficit can be overcome by addition of inorganic phosphate fertilizer $[12,13]$. The water used in decoupled aquaponics is not recirculated back to the fish once used in hydroponics, which means that nutrient adjustment cannot affect the fish. In coupled aquaponic systems, the process water circulates between the fish and the 
plant units and therefore artificial nutrient adjustment in the hydroponics may affect the fish. In the African catfish, as for all other freshwater fish species, the effects of elevated $\mathrm{PO}_{4}{ }^{3-}-\mathrm{P}$ levels on fish health, welfare and performance have not been studied. In humans, excess levels of inorganic, dietary $P$ resulted in the formation of calcium-phosphate complexes, reducing the levels of serum calcium below optimum levels and causing pathological vascular calcification [14].

The effects of dietary P deficiency on the physiology of teleosts are very well described [4], such as for grouper (Epinephelus coioides) [15], European sea bass (Dicentrarchus labrax) [16], and silver perch (Bidyanus bidyanus) [17]. Deficiency symptoms can be expressed as reduced appetite [15], growth retardation [15,16], reduced feed efficiency [15] and poor bone and scale mineralization [15]. However, the literature lacks information on the effects of increased levels of $\mathrm{PO}_{4}{ }^{3-}-\mathrm{P}$ on performance and welfare traits in commercial aquaculture species. The acute toxicity of trisodium phosphate $\left(\mathrm{Na}_{3} \mathrm{PO}_{4} 12 \mathrm{H}_{2} \mathrm{O}\right)$ on African catfish (C. gariepinus) fingerlings was studied by Ufodike [18], indicating $96 \mathrm{~h}$ lethal dose (LD) 50 of $61 \mathrm{mg} \mathrm{PO}_{4}{ }^{3-}-\mathrm{P} \mathrm{L}^{-1}$. In contrast, van Bussel et al. [19] investigated the growth, feed intake, nutrient utilization and health status of juvenile turbot (Psetta maxima) reared in intensive recirculating aquaculture systems (RAS). The authors demonstrated that levels of $82 \mathrm{mg} \mathrm{L}^{-1}$ of $\mathrm{PO}_{4}{ }^{3-}-\mathrm{P}$ did not affect the health status of the turbot, and an optimum growth, feed intake and feed efficiency could be achieved at $27 \mathrm{mg} \mathrm{L}^{-1}$. In addition, under normal operation of intensive African catfish RAS the levels of $\mathrm{PO}_{4}{ }^{3-}-\mathrm{P}$ are in the range of 18 to $34 \mathrm{mg} \mathrm{L}^{-1}$ [20], without notable mortalities. The causal link of the mortality that was observed previously [18] to $\mathrm{PO}_{4}{ }^{3-}-\mathrm{P}$ concentrations remain elusive.

Because of the relevance of African catfish in RAS and aquaponic production systems, and the recommendation to elevate $\mathrm{PO}_{4}{ }^{3-}-\mathrm{P}$ in coupled aquaponic systems for improved plant growth (30-60 mg L ${ }^{-1}$ ) [21], we assessed the effects of elevated levels of $\mathrm{PO}_{4}{ }^{3-}-\mathrm{P}$ on performance and welfare traits and other potential effects to be observed for this species. Consequently, the experimental design comprised levels of dissolved $\mathrm{PO}_{4}{ }^{3-}-\mathrm{P}$ beyond the published $\mathrm{PO}_{4}{ }^{3-}-\mathrm{P}$ challenges to approximate rearing possibilities in high accumulation aquaculture systems. Implications for a $\mathrm{PO}_{4}{ }^{3-}-\mathrm{P}$ fertilization in coupled aquaponics systems are discussed.

\section{Results}

\subsection{Water Quality}

On day one of the experiment, the water quality parameters inside the four systems ranged from: dissolved oxygen $(\mathrm{DO})=7.5-7.8 \mathrm{mg} \mathrm{L}^{-1}$, temperature $=26.3-27.3^{\circ} \mathrm{C}, \mathrm{pH}$-value $=8.5-8.8$, conductivity $=560-611 \mu \mathrm{S} \mathrm{cm}^{-1}$, redox-potential $=143-169 \mathrm{mV}, \mathrm{NH}_{4}{ }^{+}-\mathrm{N}=<0.01-0.04 \mathrm{mg} \mathrm{L}^{-1}$, $\mathrm{NO}_{2}{ }^{-}-\mathrm{N}=0.01-0.02 \mathrm{mg} \mathrm{L}^{-1}, \mathrm{NO}_{3}{ }^{-}-\mathrm{N}=2-3 \mathrm{mg} \mathrm{L}^{-1}, \mathrm{PO}_{4}{ }^{3-}-\mathrm{P}=0.1-0.2 \mathrm{mg} \mathrm{L}^{-1}, \mathrm{~K}^{+}=4-6 \mathrm{mg} \mathrm{L}^{-1}$, $\mathrm{Mg}^{2+}=9-14 \mathrm{mg} \mathrm{L}^{-1}$ and $\mathrm{Ca}^{2+}=68-87 \mathrm{mg} \mathrm{L}^{-1}$. The mean values and standard deviations of the different water quality parameters over the run of the experiment are given in Table 1.

Significant differences $(p<0.05)$ were revealed for DO, temperature, $\mathrm{pH}$-value, salinity, redox-potential, levels of $\mathrm{PO}_{4}{ }^{3-}-\mathrm{P}, \mathrm{Ca}^{2+}$ and $\mathrm{NO}_{2}{ }^{-}-\mathrm{N}$ (Kruskal-Wallis). No significant differences were revealed for conductivity, total dissolved nitrogen (TDN), $\mathrm{NH}_{4}{ }^{+}-\mathrm{N}$ and $\mathrm{NO}_{3}{ }^{-}-\mathrm{N}(p \geq 0.05)$ (Kruskal-Wallis). The DO and the temperature in P120 were lower when compared with the other groups. The highest $\mathrm{pH}$ was observed in P0, the lowest in P40 and P80. The highest salinity/conductivity was observed in P120, the lowest in P80. The highest redox-potential was observed in $\mathrm{P} 80$ and $\mathrm{P} 120$, the lowest in $\mathrm{P} 0 . \mathrm{NH}_{4}{ }^{+}-\mathrm{N}$ ranged from $2.19-2.75 \mathrm{mg} \mathrm{L}^{-1}, \mathrm{NO}_{2}-\mathrm{N}$ from $0.21-0.34 \mathrm{mg} \mathrm{L}^{-1}$. Although not significantly, total oxidized nitrogen (TON), $\mathrm{NO}_{3}{ }^{-}-\mathrm{N}, \mathrm{TDN}$ and $\mathrm{K}^{+}$ increased by trend from P0 to P120.

For $\mathrm{Ca}^{2+}$, significant differences were revealed for all groups, except between $\mathrm{P} 80$ and P40, and $\mathrm{P} 80$ and P120, with the highest concentrations in P0, and the lowest in $\mathrm{P} 120$. For $\mathrm{PO}_{4}{ }^{3-}$-P, significance was revealed for all groups except between groups $\mathrm{P} 80$ and $\mathrm{P} 120 . \mathrm{PO}_{4}{ }^{3-}-\mathrm{P}$ increased from $\mathrm{P} 0$ to P80, and by trend to $\mathrm{P} 120$. The reference group reached a mean $\mathrm{PO}_{4}{ }^{3-}-\mathrm{P}$ concentration of $3.6 \mathrm{mg} \mathrm{L}^{-1} \pm 2.4$ standard deviation (SD) due to unretained $\mathrm{P}$ by the fish. 
Table 1. Water quality parameters (mean \pm standard deviation (SD)).

\begin{tabular}{|c|c|c|c|c|c|c|}
\hline \multirow[b]{2}{*}{ Parameter } & \multicolumn{6}{|c|}{ Group } \\
\hline & Unit & P 0 & P40 & P80 & P120 & $p$-Value \\
\hline DO & $\mathrm{mg} \mathrm{L}^{-1}$ & $6.4^{\mathrm{a}} \pm 0.5$ & $6.4^{\mathrm{a}} \pm 0.6$ & $6.3^{a} \pm 0.5$ & $6.0^{b} \pm 0.6$ & $\leq 0.001$ \\
\hline DO & $\%$ & $80^{\mathrm{a}} \pm 6.2$ & $80^{\mathrm{a}} \pm 7.3$ & $80^{\mathrm{a}} \pm 6.1$ & $75^{b} \pm 7.3$ & $\leq 0.001$ \\
\hline Temperature & ${ }^{\circ} \mathrm{C}$ & $27.2^{\mathrm{a}} \pm 0.4$ & $27.1^{\mathrm{a}} \pm 0.5$ & $27.2^{a} \pm 0.2$ & $26.8^{b} \pm 0.6$ & $\leq 0.001$ \\
\hline pH-value & - & $6.5^{a} \pm 0.8$ & $6.3^{b} \pm 0.8$ & $6.2^{b} \pm 0.8$ & $6.3^{\mathrm{ab}} \pm 0.8$ & $<0.001$ \\
\hline Salinity & $\%$ & $0.50^{\mathrm{ab}} \pm 0.11$ & $0.50^{\mathrm{ab}} \pm 0.11$ & $0.49^{a} \pm 0.11$ & $0.52^{b} \pm 0.15$ & 0.044 \\
\hline Conductivity & $\mu S \mathrm{~cm}^{-1}$ & $1044 \pm 225$ & $1056 \pm 219$ & $1042 \pm 228$ & $1093 \pm 294$ & 0.114 \\
\hline Redox potential & $\mathrm{mV}$ & $165^{a} \pm 20$ & $181^{b} \pm 17$ & $187^{c} \pm 14$ & $189^{c} \pm 12$ & $\leq 0.001$ \\
\hline $\mathrm{NH}_{4}^{+}-\mathrm{N}$ & $\mathrm{mg} \mathrm{L}^{-1}$ & $2.2 \pm 3.6$ & $2.8 \pm 4.6$ & $2.6 \pm 4.2$ & $2.4 \pm 4.2$ & 0.252 \\
\hline $\mathrm{NO}_{2}{ }^{-}-\mathrm{N}$ & $\mathrm{mg} \mathrm{L}^{-1}$ & $0.34^{\mathrm{a}} \pm 0.25$ & $0.27^{\mathrm{ab}} \pm 0.35$ & $0.31^{\mathrm{ab}} \pm 0.41$ & $0.21^{b} \pm 0.16$ & 0.036 \\
\hline TON & $\mathrm{mg} \mathrm{L}^{-1}$ & $48.4 \pm 20.2$ & $49.5 \pm 20.0$ & $53.0 \pm 21.1$ & $55.2 \pm 23.6$ & 0.336 \\
\hline $\mathrm{NO}_{3}{ }^{-}-\mathrm{N}$ & $\mathrm{mg} \mathrm{L}^{-1}$ & $48.0 \pm 20.1$ & $49.2 \pm 19.5$ & $52.7 \pm 21.1$ & $55.0 \pm 23.7$ & 0.309 \\
\hline TDN & $\mathrm{mg} \mathrm{L}^{-1}$ & $50.6 \pm 22.5$ & $52.2 \pm 22.5$ & $55.7 \pm 23.9$ & $57.5 \pm 26.4$ & 0.53 \\
\hline $\mathrm{PO}_{4}{ }^{3-}-\mathrm{P}$ & $\mathrm{mg} \mathrm{L}^{-1}$ & $3.6^{\mathrm{a}} \pm 2.4$ & $39.1^{\mathrm{b}} \pm 20.6$ & $62.0^{c} \pm 30.1$ & $103.2^{\mathrm{c}} \pm 54.5$ & $\leq 0.001$ \\
\hline $\mathrm{K}^{+}$ & $\mathrm{mg} \mathrm{L}^{-1}$ & $9 \pm 7$ & $10 \pm 9$ & $10 \pm 9$ & $11 \pm 9$ & 0.199 \\
\hline $\mathrm{Mg}^{2+}$ & $\mathrm{mg} \mathrm{L}^{-1}$ & $14.9 \pm 2.2$ & $14.3 \pm 2.4$ & $13.9 \pm 2.9$ & $13.7 \pm 3.6$ & 0.2 \\
\hline $\mathrm{Ca}^{2+}$ & $\mathrm{mg} \mathrm{L}^{-1}$ & $109^{a} \pm 13$ & $94^{b} \pm 13$ & $91 \mathrm{bc} \pm 15$ & $83^{c} \pm 22$ & $\leq 0.001$ \\
\hline
\end{tabular}

Superscript letters indicate significant differences between the experimental groups $(p<0.05)$. DO: dissolved oxygen, TON: total oxidized nitrogen $\left(\mathrm{NO}_{2}{ }^{-}-\mathrm{N}+\mathrm{NO}_{3}{ }^{-}-\mathrm{N}\right)$, TDN: total dissolved nitrogen $\left(\mathrm{NH}_{4}{ }^{-}-\mathrm{N}+\mathrm{NO}_{2}{ }^{-}-\mathrm{N}+\mathrm{NO}_{3}{ }^{-}-\mathrm{N}\right)$.

With increased addition of $\mathrm{PO}_{4}{ }^{3-}-\mathrm{P}$ to the three test groups, the water increasingly turned milky. The intensity of milkiness (impression of the observers) reduced over the course of the experiment but remained until the end. On the last day of the experiment, the water quality parameters differed from the conditions of day one and ranged from: $\mathrm{DO}=6.2-6.9 \mathrm{mg} \mathrm{L}^{-1}$, temperature $=25.7-27.0^{\circ} \mathrm{C}$, $\mathrm{pH}$-value $=4.67-5.94$, conductivity $=1099-1151 \mu \mathrm{S} \mathrm{cm}{ }^{-1}$, redox-potential $=165-218 \mathrm{mV}, \mathrm{NH}_{4}{ }^{-}-\mathrm{N}=$ 8.38-10.39 $\mathrm{mg} \mathrm{L}^{-1}, \mathrm{NO}_{2}{ }^{-}-\mathrm{N}=0.09-0.16 \mathrm{mg} \mathrm{L}^{-1}, \mathrm{NO}_{3}{ }^{-}-\mathrm{N}=81-95 \mathrm{mg} \mathrm{L}^{-1}, \mathrm{PO}_{4}{ }^{3-}-\mathrm{P}=7.6-97.2 \mathrm{mg} \mathrm{L}^{-1}$, $\mathrm{K}^{+}=16-33 \mathrm{mg} \mathrm{L}^{-1}, \mathrm{Mg}^{2+}=12-16 \mathrm{mg} \mathrm{L}^{-1}$ and $\mathrm{Ca}^{2+}=101-111 \mathrm{mg} \mathrm{L}^{-1}$.

\subsection{Fish Performance and Body Composition}

During the experiment, three animals died in the group P0, two in P80, while no mortality was observed in the groups P40 and P120. After acclimatization, fish always ate the scheduled daily ratio. The means and SD of the fish growth performance parameters are given in Table 2. Final weight, total length, standard length, growth, fillet ratio, specific growth rate (SGR), feed conversion ratio (FCR), and total feed intake (TFI) showed no significant differences between the treatment groups $(p \geq 0.05)$.

Table 2. Fish growth and feed efficiency of C. gariepinus (mean $\pm \mathrm{SD}$ ).

\begin{tabular}{ccccccc}
\hline \multicolumn{7}{c}{ Group } \\
\hline Parameter & Unit & P0 & P40 & P80 & P120 & $p$-Value * \\
\hline Final weight $\left(\mathrm{W}_{\mathrm{t}}\right)$ & $\mathrm{g} \mathrm{fish}^{-1}$ & $132.9 \pm 34.1$ & $148.9 \pm 51.4$ & $161.3 \pm 44.0$ & $159.6 \pm 46.8$ & 0.822 \\
Total length & $\mathrm{cm}$ & $27.3 \pm 2.4$ & $28.0 \pm 3.3$ & $28.9 \pm 2.5$ & $28.3 \pm 2.3$ & 0.615 \\
Standard length & $\mathrm{cm}$ & $24.4 \pm 2.1$ & $25.1 \pm 3.0$ & $25.9 \pm 2.3$ & $25.4 \pm 2.4$ & 0.627 \\
Growth (G) & g fish $^{-1}$ & $105.8 \pm 3.5$ & $118.8 \pm 1.1$ & $128.5 \pm 3.0$ & $126.4 \pm 4.5$ & 0.153 \\
Fillet ratio & $\%$ & $33.3 \pm 2.3$ & $32.3 \pm 3.4$ & $33.9 \pm 1.9$ & $33.5 \pm 2.2$ & 0.155 \\
SGR & $\%$ & $2.64 \pm 0.05$ & $2.66 \pm 0.03$ & $2.6 \pm 0.05$ & $2.61 \pm 0.03$ & 0.172 \\
FCR & - & $0.72 \pm 0.05$ & $0.71 \pm 0.01$ & $0.71 \pm 0.03$ & $0.73 \pm 0.02$ & 0.450 \\
TFI & g fish $^{-1}$ & $76.0 \pm 1.1$ & $84.1 \pm 1.9$ & $91.3 \pm 5.2$ & $92.8 \pm 2.2$ & 0.266 \\
\hline
\end{tabular}

Superscript letters indicate significant differences between the experimental groups $(p<0.05) .{ }^{*} p$-value taken from analysis of variance (ANOVA)/Kruskal-Wallis. SGR: specific growth rate, FCR: feed conversion ratio, TFI: total feed intake.

The mean values of the body composition of the baseline, as well as the control and the experimental groups, are given for whole fish in Table 3 and fillet in Table 4. Except for the fat content in the fillets, no significant differences were found in the whole body and the fillet composition. 
The fat content in the fillet was significantly higher in P120 when compared with P0. By trend, the fat content in the fillet and the Ca content in the whole fish increased from group P0 to P120.

Table 3. Initial and final body composition of C. gariepinus $(\mathrm{n}=3)$.

\begin{tabular}{cccccccc}
\hline \multicolumn{7}{c}{ Group } \\
\hline Parameter & Unit & Baseline & P0 & P40 & P80 & P120 & $\boldsymbol{p}_{\text {-Value * }}$ \\
\hline Dry matter & $\mathrm{g} \mathrm{kg}^{-1}, \mathrm{wW}$ & 207 & $247 \pm 13$ & $253 \pm 1$ & $252 \pm 8$ & $270 \pm 8$ & 0.146 \\
Ash & $\mathrm{g} \mathrm{kg}^{-1}, \mathrm{dm}$ & 131 & $128 \pm 10$ & $136 \pm 8$ & $131 \pm 5$ & $132 \pm 6$ & 0.780 \\
Protein & $\mathrm{g} \mathrm{kg}^{-1}, \mathrm{dm}$ & 694 & $668 \pm 13$ & $644 \pm 18$ & $664 \pm 17$ & $645 \pm 2$ & 0.275 \\
Fat & $\mathrm{g} \mathrm{kg}^{-1}, \mathrm{dm}$ & 97 & $146 \pm 19$ & $146 \pm 17$ & $139 \pm 11$ & $165 \pm 10$ & 0.401 \\
Calcium & $\mathrm{g} \mathrm{kg}^{-1}, \mathrm{dm}$ & 36.8 & $30.2 \pm 6.9$ & $31.3 \pm 4.8$ & $33.3 \pm 3.1$ & $37.1 \pm 5.0$ & 0.570 \\
Phosphorus & $\mathrm{g} \mathrm{kg}^{-1}, \mathrm{dm}$ & 25.3 & $23.7 \pm 2.8$ & $22.9 \pm 1.4$ & $24.3 \pm 1.1$ & $24.4 \pm 2.7$ & 0.893 \\
Sodium & $\mathrm{g} \mathrm{kg}^{-1}, \mathrm{dm}$ & 4.6 & $4.8 \pm 0.7$ & $3.9 \pm 0.7$ & $4.5 \pm 0.4$ & $4.2 \pm 0.8$ & 0.612 \\
Magnesium & $\mathrm{g} \mathrm{kg}^{-1}, \mathrm{dm}$ & 1.5 & $1.7 \pm 0.2$ & $1.5 \pm 0.2$ & $1.6 \pm 0.2$ & $1.4 \pm 0.1$ & 0.412 \\
Potassium & $\mathrm{g} \mathrm{kg}^{-1}, \mathrm{dm}$ & 14.6 & $11.4 \pm 0.8$ & $12.0 \pm 1.3$ & $12.8 \pm 0.6$ & $12.1 \pm 0.6$ & 0.520 \\
\hline
\end{tabular}

Superscript letters indicate significant differences between the experimental groups $(p<0.05) .{ }^{*}$ : $p$-value based on comparison of P0, P40, P80, and P120. $p$-value taken from ANOVA/Kruskal-Wallis. ww: wet weight, dm: dry matter.

Table 4. Initial and final fillet composition of C. gariepinus $(\mathrm{n}=3)$.

\begin{tabular}{cccccccc}
\hline & \multicolumn{7}{c}{ Group } \\
\hline Parameter & Unit & Baseline & P0 & P40 & P80 & P120 & $p$-Value * \\
\hline Dry matter & $\mathrm{g} \mathrm{kg}^{-1}, \mathrm{ww}$ & 206 & $222 \pm 7$ & $222 \pm 4$ & $222 \pm 6$ & $216 \pm 10$ & 0.965 \\
Ash & $\mathrm{g} \mathrm{kg}^{-1}, \mathrm{dm}$ & 65 & $58 \pm 1$ & $57 \pm 2$ & $55 \pm 2$ & $55 \pm 1$ & 0.169 \\
Protein & $\mathrm{g} \mathrm{kg}^{-1}, \mathrm{dm}$ & 873 & $836 \pm 4$ & $851 \pm 5$ & $827 \pm 10$ & $836 \pm 5$ & 0.073 \\
Fat & $\mathrm{g} \mathrm{kg}^{-1}, \mathrm{dm}$ & 46 & $81^{\mathrm{a}} \pm 7$ & $101^{\mathrm{ab}} \pm 8$ & $105^{\mathrm{ab}} \pm 6$ & $110^{\mathrm{b}} \pm 13$ & 0.042 \\
Calcium & $\mathrm{g} \mathrm{kg}^{-1}, \mathrm{dm}$ & 2.4 & $0.8 \pm<0.1$ & $0.7 \pm 0.1$ & $0.8 \pm<0.1$ & $0.5 \pm 0.1$ & 0.094 \\
Phosphorus & $\mathrm{g} \mathrm{kg}^{-1}, \mathrm{dm}$ & 12.3 & $10.2 \pm 0.1$ & $10.2 \pm 0.4$ & $10.3 \pm 0.2$ & $10.0 \pm 0.1$ & 0.475 \\
Sodium & $\mathrm{g} \mathrm{kg}^{-1}, \mathrm{dm}$ & 2.5 & $2.2 \pm 0.2$ & $2.0 \pm 0.2$ & $1.8 \pm 0.4$ & $1.8 \pm 0.1$ & 0.725 \\
Magnesium & $\mathrm{g} \mathrm{kg}^{-1}, \mathrm{dm}$ & 1.6 & $1.4 \pm 0.1$ & $1.4 \pm<0.1$ & $1.3 \pm<0.1$ & $1.4 \pm<0.1$ & 0.179 \\
Potassium & $\mathrm{g} \mathrm{kg}^{-1}, \mathrm{dm}$ & 21 & $19 \pm 2$ & $20 \pm 2$ & $18 \pm 1$ & $18 \pm 1$ & 0.458 \\
\hline
\end{tabular}

Superscript letters indicate significant differences between the experimental groups $(p<0.05) .{ }^{*} p$-value based on comparison of P0, P40, P80, and P120. $p$-value taken from ANOVA/Kruskal-Wallis if $p \geq 0.05$, and from Post-Hoc if $p$-value from ANOVA/Kruskal-Wallis $<0.05$.

No significant differences in the values of the apparent net nutrient utilization (ANNU) were found (Table 5). By trend, the ANNUs of Ca and P increased from group P0 to P120, and the ANNU of protein increased by trend slightly from P40 to P120.

Table 5. Apparent net nutrient utilization of C. gariepinus \%.

\begin{tabular}{cccccc}
\hline \multicolumn{7}{c}{ Group } \\
\hline Parameter & P0 & P40 & P80 & P120 & $p$-Value * \\
\hline Protein & $46.3 \pm 3.1$ & $46.2 \pm 1.6$ & $47.6 \pm 1.6$ & $48.3 \pm 2.5$ & 0.760 \\
Fat & $52.4 \pm 11.3$ & $53.7 \pm 6.8$ & $50.7 \pm 4.8$ & $64.0 \pm 4.5$ & 0.333 \\
Calcium & $46.2 \pm 14.0$ & $50.5 \pm 10.0$ & $54.2 \pm 6.8$ & $65.0 \pm 12.0$ & 0.589 \\
Phosphorus & $54.1 \pm 8.0$ & $54.2 \pm 3.7$ & $57.8 \pm 2.8$ & $61.0 \pm 9.3$ & 0.686 \\
Sodium & $40.5 \pm 4.3$ & $32.9 \pm 7.0$ & $39.1 \pm 3.9$ & $38.1 \pm 7.3$ & 0.740 \\
Magnesium & $33.2 \pm 4.0$ & $31.5 \pm 4.7$ & $32.1 \pm 5.4$ & $28.7 \pm 3.6$ & 0.784 \\
Potassium & $38.4 \pm 4.4$ & $42.4 \pm 6.0$ & $45.7 \pm 2.9$ & $44.9 \pm 5.1$ & 0.455 \\
\hline
\end{tabular}

Superscript letters indicate significant differences between the experimental groups $(p<0.05) .{ }^{*} p$-value based on comparison of P0, P40, P80, and P120. $p$-value taken from ANOVA/Kruskal-Wallis. 


\subsection{Welfare}

The examination of the gills revealed no structural changes of the epithelial tissues, the primary and secondary lamella or the mucous cells (Figure 1).

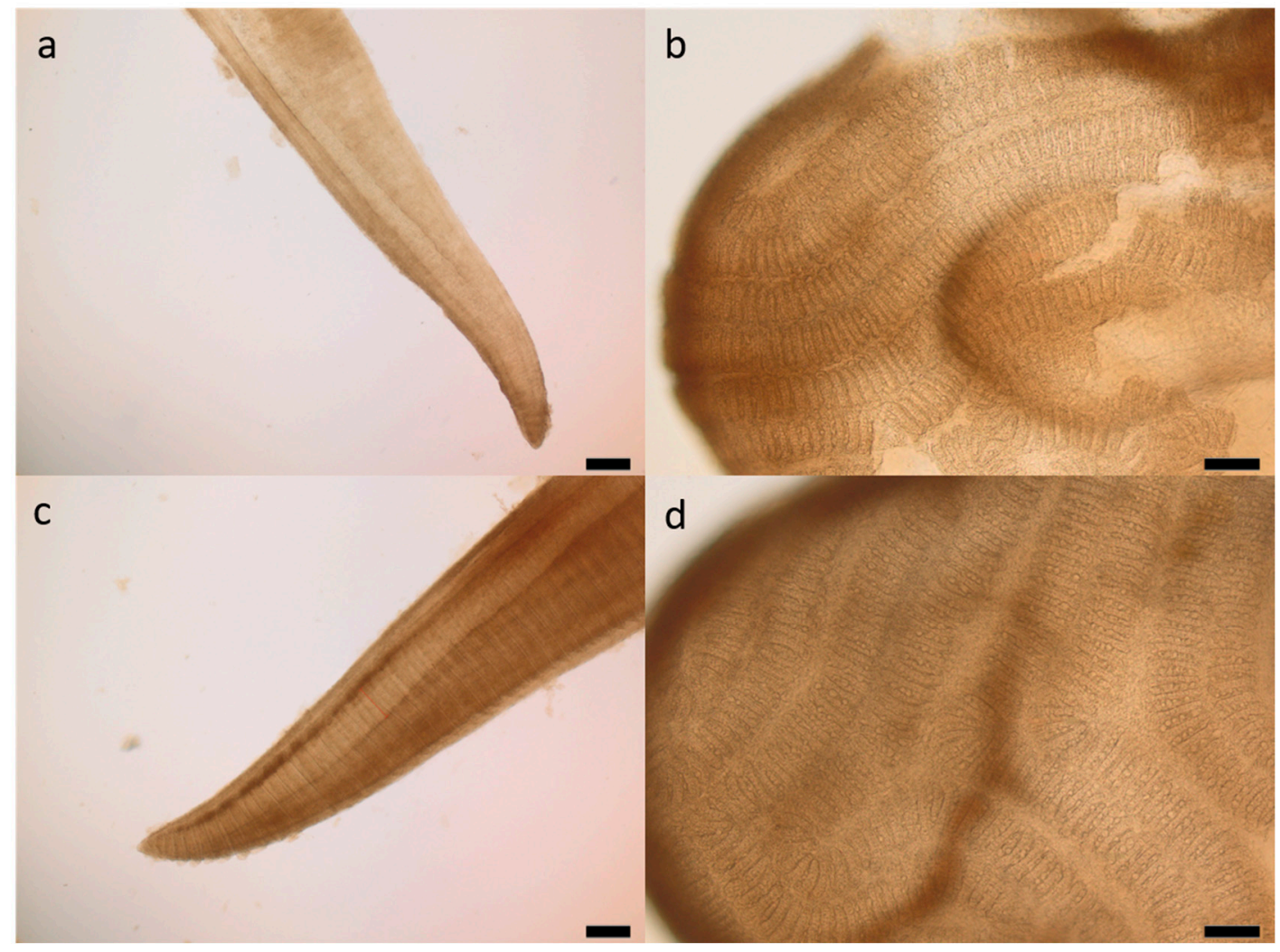

Figure 1. Gill filament of the P0 group $(\mathbf{a}, \mathbf{b})$ and the P120 group $(\mathbf{c}, \mathbf{d})$ without notable changes, scale bar $200 \mu \mathrm{m}(\mathbf{a}, \mathbf{c})$ and $100 \mu \mathrm{m}(\mathbf{b}, \mathbf{d})$.

The mean values and SD of the welfare indicators based on the skin coloration, plasma metabolites, and the behavioral analyses are given in Table 6. Significant differences $(p<0.05)$ in skin coloration (Kruskal-Wallis) were observed with the palest fish in P80 and P120 and the darkest in P40 (skin darkness: P40 > P80, P120).

For the functional blood parameters, significant differences $(p<0.05)$ were revealed for plasma concentrations of inorganic P between P120 and P0 and P40 (variance analysis, PROC MIXED). No significant differences were revealed for plasma $\mathrm{Ca}, \mathrm{NH}_{4}{ }^{+}$, glucose and cortisol. Plasma concentrations of inorganic $\mathrm{P}$ was increased in animals kept at P120 compared to animals kept at P0 and P40 $(\mathrm{P} 0 \leq \mathrm{P} 120 ; \mathrm{P} 40 \leq \mathrm{P} 120)$.

The behavioral responses of $C$. gariepinus were slightly altered between the treatment groups (Table 6). Significant differences $(p<0.05)$ were observed within swimming activity (analysis of variance (ANOVA)), air breathing (ANOVA), and the number of biting wounds (Kruskal-Wallis), with lowest swimming activity and air breathing, but most biting wounds in the P120 group. The number of biting wounds was numerically lowest in P0, but no significant difference ( $p \geq 0.05)$ (Kruskal-Wallis) was detected between P0 and P80, and P40 and P120. By trend, the observed agonistic behavior (group), swimming activity and air breathing reduced with increasing concentrations of $\mathrm{PO}_{4}{ }^{3-}-\mathrm{P}$. 
Table 6. Health and welfare indicators-plasma metabolites and skin darkness and behavior of C. gariepinus challenged with different amounts of dissolved phosphate (means \pm SD).

\begin{tabular}{|c|c|c|c|c|c|c|}
\hline \multicolumn{7}{|c|}{ Plasma Metabolites } \\
\hline \multirow[b]{2}{*}{ Parameter } & \multicolumn{6}{|c|}{ Group } \\
\hline & Unit & P0 & $\mathbf{P} 40$ & P80 & P120 & $p$-Value \\
\hline Inorganic phosphorus & $\mathrm{mg} \mathrm{dL}^{-1}$ & $6.22^{a} \pm 0.57$ & $6.28^{a} \pm 0.94$ & $6.68^{\mathrm{ab}} \pm 0.69$ & $7.17^{\mathrm{b}} \pm 1.14$ & 0.028 \\
\hline Calcium & $\mathrm{mg} \mathrm{dL}-1$ & $14.27 \pm 1.30$ & $14.44 \pm 1.09$ & $14.68 \pm 1.13$ & $14.39 \pm 0.92$ & 0.740 \\
\hline Ammonia & $\mu \mathrm{g} \mathrm{dL}-1$ & $409 \pm 172$ & $400 \pm 234$ & $338 \pm 79$ & $344 \pm 91$ & 0.514 \\
\hline Blood glucose & $\mathrm{mmol} \mathrm{L}^{-1}$ & $2.34 \pm 0.39$ & $2.21 \pm 0.43$ & $2.44 \pm 0.58$ & $2.35 \pm 0.42$ & 0.492 \\
\hline Plasma cortisol & $\mathrm{ng} \mathrm{mL} L^{-1}$ & $28.5 \pm 13.3$ & $26.9 \pm 19.9$ & $26.4 \pm 10.3$ & $29.0 \pm 17.0$ & 0.716 \\
\hline Skin darkness & - & $6.2^{\mathrm{ab}} \pm 1.6$ & $7.2^{\mathrm{a}} \pm 1.1$ & $5.5^{b} \pm 1.7$ & $5.3^{b} \pm 1.8$ & $<0.001$ \\
\hline \multicolumn{7}{|c|}{ Behavior } \\
\hline Biting wounds & $n$ & $2.6^{\mathrm{a}} \pm 2.5$ & $4.5^{b} \pm 3.7$ & $4.0^{\mathrm{ab}} \pm 3.6$ & $5.4^{b} \pm 4.3$ & 0.002 \\
\hline $\begin{array}{l}\text { Swimming activity } \\
\text { (group) }\end{array}$ & $\%$ & $61.5^{\mathrm{a}} \pm 22.0$ & $53.5^{a b} \pm 20.2$ & $56.4^{\mathrm{ab}} \pm 24.5$ & $44.4^{b} \pm 29.9$ & 0.002 \\
\hline Air breathing (group) & $n$ & $19.7^{\mathrm{a}} \pm 5.4$ & $15.2^{\mathrm{ab}} \pm 9.4$ & $13.5^{\mathrm{ab}} \pm 9.3$ & $5.2^{b} \pm 2.6$ & 0.003 \\
\hline $\begin{array}{c}\text { Agonistic behavior } \\
\text { (group) }\end{array}$ & $n$ & $13.7 \pm 9.9$ & $11.3 \pm 5.7$ & $8.5 \pm 4.5$ & $5.8 \pm 3.3$ & 0.164 \\
\hline $\begin{array}{l}\text { Swimming activity } \\
\text { (individual) }\end{array}$ & $\%$ & $62.6 \pm 17.3$ & $55.7 \pm 22.9$ & $50.3 \pm 15.5$ & $43.6 \pm 11.2$ & 0.383 \\
\hline $\begin{array}{l}\text { Air breathing } \\
\text { (individual) }\end{array}$ & $\%$ & $3.7 \pm 1.4$ & $2.3 \pm 0.8$ & $2.3 \pm 2.3$ & $1.8 \pm 1.5$ & 0.197 \\
\hline $\begin{array}{l}\text { Agonistic behavior } \\
\text { (individual) }\end{array}$ & $n$ & $2.8 \pm 1.7$ & $3.3 \pm 2.1$ & $2.2 \pm 1.3$ & $2.7 \pm 2.8$ & 0.541 \\
\hline
\end{tabular}

Superscript letters indicate significant differences between the experimental groups $(p<0.05)$.

\section{Discussion}

This is the first time that effects of elevated concentrations of $\mathrm{PO}_{4}{ }^{3-}-\mathrm{P}$ in the rearing water were studied on the growth performance and welfare of African catfish. Medium increase in $\mathrm{PO}_{4}{ }^{3-}-\mathrm{P}$ concentrations were without significant effects, while the level of $120 \mathrm{mg} \mathrm{L}^{-1} \mathrm{PO}_{4}{ }^{3-}$-P affected behavior and welfare.

\subsection{Water Quality}

At the beginning of the experiment (d1), the water quality was similar between the treatment groups, with high $\mathrm{DO}$ and $\mathrm{pH}$-values, low conductivity, high redox potential and very low levels of $\mathrm{NH}_{4}{ }^{+}-\mathrm{N}, \mathrm{NO}_{2}{ }^{-}-\mathrm{N} \mathrm{NO}_{3}{ }^{-}-\mathrm{N}$, and $\mathrm{PO}_{4}{ }^{3-}-\mathrm{P}$, originating from the properties of the aerated tap water. Although the $\mathrm{pH}$ dropped over the course of the experiment, this change took place during the first 20 days in a continuing manner, allowing the fish to acclimatize to these changing conditions.

Addition of $\mathrm{P}_{2} \mathrm{O}_{5}$ did not simply result in proportional increase of $\mathrm{PO}_{4}{ }^{3-}-\mathrm{P}$ concentrations inside the water. This disproportional response was probably a result of precipitation of $\mathrm{PO}_{4}{ }^{3-}-\mathrm{P}$ with $\mathrm{Ca}^{2+}$ and $\mathrm{Mg}^{2+}$ a phenomenon which is well understood [22,23]. This is supported by the increasing turbidity of the process water, significantly decreasing levels of dissolved $\mathrm{Ca}^{2+}(p<0.05)$, and by the trend of decreasing levels of dissolved $\mathrm{Mg}^{2+}$ after addition of $\mathrm{P}_{2} \mathrm{O}_{5}$. Using a protocol based on $\mathrm{P}_{2} \mathrm{O}_{5}$ dose and analytical response, the target levels of P40 and P80 were achieved. By trend, the levels of $\mathrm{PO}_{4}{ }^{3-}-\mathrm{P}$ in the group P120 mostly remained above the other concentrations with a high standard deviation, while the P0 group in maximum reached $8.9 \mathrm{mg} \mathrm{L}^{-1}$ caused by natural excretion of the fish.

Only minor differences in the water quality parameters were observed between the groups. $\mathrm{K}^{+}$, $\mathrm{NH}_{4}{ }^{+}-\mathrm{N}$ and to lesser extent $\mathrm{NO}_{2}{ }^{-}-\mathrm{N}$ started to accumulate from day 30 , in all systems, indicating an overload of the biofilters. As regular water exchange remained, the water quality parameters were well appropriate for C. gariepinus [24-27]. Given that our statistical analysis revealed significant differences in DO, temperature, $\mathrm{pH}$-value and redox-potential between the groups, we cannot rule out minor influence on our results. However, due to the small magnitudes of these values, and because of the 
inevitable precipitation of $\mathrm{Ca} / \mathrm{Mg}$-phosphates, we estimate the observed effects to be monofactorial, resulting from the major differences in $\mathrm{PO}_{4}{ }^{3-}-\mathrm{P}$.

\subsection{Mortality and Growth Performance}

The mortality during the experiment was very low (2.6\%). Considering that of five dead fish three died in $\mathrm{P} 0$ and two in $\mathrm{P} 80$, the mortality was likely not a result of the increased $\mathrm{PO}_{4}{ }^{3-}-\mathrm{P}$ concentrations in the rearing water.

For juvenile African catfish, we presumed an exponential growth (body weight $\mathrm{d}_{0} \times \exp ^{(\mathrm{k} \times \mathrm{t})}$, with $\mathrm{k}=$ specific growth rate and $\mathrm{t}=$ days of the experiment). From our own previously recorded experimental data [20], we presumed a FCR of 1.0 and a daily feed ratio of 2.2. The FCR turned out to be lower (0.71-0.73), which can be considered as normal for smaller/younger fish $[11,28]$. After the acclimatization period, the fish always ate their scheduled ratio, but appeared to be close to maximum feed intake, which is important in commercial systems to maximize growth. The daily feed ratio was therefore also comparable with that of commercial systems, so we estimated it to be appropriate.

The dietary composition of the commercial feed, especially the levels of $\mathrm{P}$, was adequate according to the literature [4]. Although feed intake appeared to increase with elevated levels of $\mathrm{PO}_{4}{ }^{3-}-\mathrm{P}$, this was not a result of increased appetite but in correspondence with the feeding curve and based on the initial body weight. Using the initial life weight as co-variant, no significant differences in TFI were observed. Consequently, optimum FCR $(0.71)$ and SGR $\left(2.66 \% \mathrm{~d}^{-1}\right)$ were by trend best in P40 and P80. Similar positive effects in response to moderately increased concentrations of $\mathrm{PO}_{4}{ }^{3-}-\mathrm{P}$ were also observed with turbot (Psetta maxima) [19] and tilapia (Oreochromis niloticus) [29].

The analysis of the whole fish revealed that body composition was in line with literature data, with only the levels of $\mathrm{P}, \mathrm{Ca}$ and protein being higher, and the largest difference in direct comparison in the group P120 [30-32]. The analysis of the fillets revealed a higher content of ash and protein in our study, a lower fat content, and minerals in a similar range [33-35]. In our study, the analyzed fillets revealed higher proportions of ash, partially higher or comparable protein levels and similar or lower fat contents $[31,32,34,35]$. The levels of mineral contents were in range with literature data or even higher [31-33]. For commercially produced African catfish (C. gariepinus) fillet from intensive production in Germany, Wasenitz et al. [36] found lower levels for ash and $\mathrm{P}_{2} \mathrm{O}_{5} 4.2 \mathrm{~g} \mathrm{~kg}^{-1}$ wet weight (ww) (value converted into $P$ was $1.84 \mathrm{~g} \mathrm{~kg}^{-1}$, in ww) and higher values for dry matter and protein. Wasenitz et al. [36] determined almost double values for fat when compared to our data.

An interesting observation is the difference in $\mathrm{P}$ and Ca content between the juvenile fish at the beginning of the experiment (baseline) and the final body composition. The juvenile fish were fed with starter feed, containing higher levels of $\mathrm{P}$, protein and lower levels of fat. The young fish had higher levels of $\mathrm{Ca}$ and $\mathrm{P}$ when compared with the final body composition of the fish at the end of the experiment, which was reduced by about $18 \%(\mathrm{Ca})$ in P0. They had neither access to a carnivorous natural diet with higher $\mathrm{P} / \mathrm{Ca}$ contents when compared with the commercial growth out feed, soluble $\mathrm{P}$, nor to sediments with organic/inorganic $\mathrm{P}$ deposits like fish in natural habitats. With increasing $\mathrm{PO}_{4}{ }^{3-}-\mathrm{P}$ concentrations inside the water, the $\mathrm{Ca} / \mathrm{P}$ content in the body also increased. This indicates that the P-content in the water influences the mineralization status of the fish bones, where most $\mathrm{Ca} / \mathrm{P}$ is deposited. We also observed that, if $\mathrm{PO}_{4}{ }^{3-}-\mathrm{P}$ increases, the fat content increases. This suggests that the fat content in the fillet can be manipulated via the levels of $\mathrm{PO}_{4}{ }^{3-}-\mathrm{P}$ in the water. Our data demonstrate that the fish is able to uptake $\mathrm{PO}_{4}{ }^{3-}-\mathrm{P}$ directly from the water, and requires adequate $\mathrm{P}$ concentrations to build up fat. The fish held in the $\mathrm{P0}$ group with $\mathrm{PO}_{4}{ }^{3-}-\mathrm{P}<2.6 \mathrm{mg} \mathrm{L}^{-1}$ most likely mobilized $\mathrm{P}$ from the bones and were therefore unable to keep up with the growth when compared with the fish in P40 and P80. As a consequence, generally elevated levels of $\mathrm{PO}_{4}{ }^{3-}-\mathrm{P}$ between $40-80 \mathrm{mg} \mathrm{L}^{-1}$ inside the rearing water increase the growth potential of African catfish RAS, because of higher feed efficiency. The content of $\mathrm{P}$ inside the fillets was rather constant at about $1 \%$ on a dry matter $(\mathrm{dm})$ basis. 
When challenged with elevated levels of $\mathrm{PO}_{4}{ }^{3-}-\mathrm{P}$, African catfish increased the ANNUs of Ca and $\mathrm{P}$ by trend up to $120 \mathrm{mg} \mathrm{L}^{-1}$, indicating higher bone mineralization [15]. Likewise, the ANNU of protein slightly increased by trend from group P40 to P120. Table 5 shows that the ANNU-efficiencies of $\mathrm{Ca}$ and $\mathrm{P}$ increase under elevated levels of $\mathrm{PO}_{4}{ }^{3-}$-P. Because the feed was the same in all groups, the difference of $\mathrm{P}$ between $\mathrm{P} 0$ and the other groups is a result of utilization of $\mathrm{PO}_{4}{ }^{3-}-\mathrm{P}$ from the water, allowing better mineralization of the bones, which is also evident in the higher utilization efficiency of $\mathrm{Ca}$ under elevated $\mathrm{PO}_{4}{ }^{3-}-\mathrm{P}$. This effect obviously occurs under the use of $\mathrm{P}$ limited diets.

Growth can be defined as the assimilation of energy in the form of fat and protein. To be available for growth, the gross fat and protein from feed (net energy) must be: (1) digestible; (2) metabolizable; and (3) not required for maintenance energy expenditure [2,37]. Maintenance energy expenditure is the sum of energy used for swimming activity and the maintenance metabolism, the vital life functions [38]. The partition of energy allocated to maintenance is substantial, as it accounts for about $15-30 \%$ of the gross energy intake [39]. If growth is increased under restrictive feeding (our impression was that fish were not fully satiated), the observed trend in the P120 must result from reduced maintenance energy expenditure, resulting from elevated levels of $\mathrm{PO}_{4}{ }^{3-}-\mathrm{P}$. We observed that the catfish significantly reduced their activity under increased concentrations of $\mathrm{PO}_{4}{ }^{3-}-\mathrm{P}$ (further discussed in Section 3.3), possibly allowing the fish to utilize feed derived energy and nutrients for growth.

In fish, the maintenance metabolism is mainly dominated by ionic and osmotic regulation [40]. Also the maintenance of phosphorus requires energy. If dietary P is deficient, increased effort (energy) has to be invested to maintain P-homeostasis. Fish are able to uptake P from the water [41]. The primary and subsequent uptake pathways for organic or inorganic P in African catfish were not assessed, however, in trout these were identified in the proximal and distal intestine, subordinate uptake is provided by the gills [42,43]. Reabsorption and excretion of $\mathrm{P}$ from the urine is provided through the kidneys [44]. It can be speculated that additional supply of $\mathrm{P}$ to the water allowed the animal to reduce the energy expenditure for $P$ uptake from feed and water via intestine and the gills, and possibly for renal resorption. This energy could be incorporated as fat.

Considering that an increase in $\mathrm{PO}_{4}{ }^{3-}-\mathrm{P}$ also slightly increased protein assimilation efficiency (from $\mathrm{P} 40$ to $\mathrm{P} 120$ ), the elevated concentrations of body fat content under high $\mathrm{PO}_{4}{ }^{3-}-\mathrm{P}$ are unlikely a result of increased lipogenesis of dietary protein, but rather a direct deposition of dietary fat. Consequently, either the concentrations or the digestibility of the dietary P was too low (the feed specifications indicate only plant and animal $\mathrm{P}$ sources), or that the uptake via the intestine was exhausted. In either case, $\mathrm{PO}_{4}{ }^{3-}-\mathrm{P}$ will be used to supplement the needs of the animal. It is conceivable that the variation of $\mathrm{PO}_{4}{ }^{3-}-\mathrm{P}$ in the water prompted intrinsic responses of major players of $\mathrm{P}$ homeostasis. Indeed, studies in fish and mammals showed that the dietary $\mathrm{P}$ supply impacts on various tissue sites and body compartments such as gut, kidney and bone [45-47]. However, molecular specificities of associated regulators, transporters, and endocrine and paracrine signals are largely unknown and yet to be elucidated in African catfish. It should be noted that levels of $\mathrm{NH}_{4}{ }^{+}$and glucose remained unaffected by treatments which indicate regular nutrient utilization and energy homeostasis. Serum $\mathrm{Ca}^{2+}$ and $\mathrm{NH}_{4}{ }^{+}$remained unaffected by the treatment, therefore the homeostasis/excretion via the kidney was likely not impaired [25,44,48].

\subsection{Welfare}

The welfare of fish is usually studied via functional and behavioral approaches. Functional approaches are used to evaluate whether an animal can cope physiologically with its environmental or husbandry conditions. Behavioral approaches are used to evaluate the ability to perform natural behavioral patterns [49]. Environmental influences, primarily changes in water quality, can adversely affect fish welfare [50-52]. Thus, it is possible that the physiology, in particular stress response reactions, is influenced [53,54]. Accordingly, behavioral changes may also occur.

We observed that with increasing concentrations of $\mathrm{PO}_{4}{ }^{3-}-\mathrm{P}$, African catfish shifted towards a lighter grey tone of the skin. Catfish are able to alter their skin coloration to lighter or darker. 
Melanosomes inside the skin are responsible for this action, as they may change in number and size $[55,56]$. Different mechanisms causing this change are described, such as adaptation to the background color [57,58] and light regime [59] of their environment, dietary composition [60], hormones [55] and environmental stress [61]. A direct effect of $\mathrm{PO}_{4}{ }^{3-}-\mathrm{P}$ in the water on the skin coloration of fish is not described in literature. However, the skin of the scaleless African catfish could also be affected in regard to mineralization [15]. It is known that the mineralization of the skin can be affected by dietary P [62]. In this case, the lighter skin coloration would be the result of calcium-phosphates that precipitated inside the skin $[17,63]$, to be tested in subsequent studies.

Alterations of the cortisol level is often used as an indicator for stress in welfare investigations [43], because it reflects acute and long-term (chronic) stress [53,64]. Cortisol production can be influenced by environmental impacts, such as pollutants in the water [54]. To our knowledge, there is no study addressing cortisol changes resulting from increased $\mathrm{PO}_{4}{ }^{3-}-\mathrm{P}$ concentrations in the rearing water available. In our study, we did not find significant differences in the plasma cortisol response between the treatment groups. Slightly elevated plasma cortisol levels due to netting stress occurred over the course of the sampling procedure. Under this consideration, the plasma cortisol amplitude increased regularly with ongoing sampling in every group but was not affected by the $\mathrm{PO}_{4}{ }^{3-}-\mathrm{P}$ concentration in the rearing water. This also demonstrated that an alteration of the cortisol level due to $\mathrm{PO}_{4}{ }^{3-}-\mathrm{P}$ concentration did not occur. Alterations of the blood glucose concentrations were similar in all groups and in a typical range for C. gariepinus [65]. Further effects such as immuno- and growth-depression as a consequence of chronic hypercortisolism [44] could not be observed in our study. Therefore, we suggest that the stress level following $\mathrm{PO}_{4}{ }^{3-}-\mathrm{P}$ exposure below $80 \mathrm{mg} \mathrm{L}^{-1}$ can be considered as low.

In the P120 group, the fish altered their agonistic behavior, also seen in the highest number of biting wounds compared with P0 to P80. However, differences between P40, P80 and P120, or P0 and P80 were not significant. This trend correlated with significantly less group air breathing and swimming activity from P0 towards P120, leading to the assumption that the observed elevation in the number of biting wounds was due to behavioral changes. One explanation is an adaption to the water conditions, in particular regarding turbidity. African catfish have only poorly developed eyes [66] and are nocturnal. It can be speculated, that inside the turbid water, the fish react differently on each other; therefore interaction (visual, tactile sense) only occurs when the animals are very close, triggering a more aggressive response, such as biting (discussed in Baßmann et al. [65]). African catfish are normally territorial animals. Under high stocking density, this territorial behavior is suppressed, and the fish tend to school up and spend much time resting, provided that feed and DO are adequate. Under high concentrations of DO, the African catfish is described as a faculatative air breather [67]. If however, the fish returns from air breathing at the surface, finding a resting place may disrupt the school and trigger an aggressive response in other fish. Because African catfish are more active at twilight and/or night, Britz and Pienaar [68] demonstrated a link between light intensity, swimming activity, air breathing and agonistic behavior, resulting in injuries and cannibalism. When exposed to bright light, the animals in these studies were less active and reduced air breathing, but spend more time resting, were more territorial and had increased numbers of injuries. This is corresponding to our results. Possibly, the diffuse light conditions during the day in our experiments in combination with the increased water turbidity under high $\mathrm{PO}_{4}{ }^{3-}-\mathrm{P}$ is perceived brighter than without turbidity by the fish. To find out which exact mechanism (e.g., the visual or tactile sense) caused the increased number in biting wounds under high $\mathrm{PO}_{4}{ }^{3-}-\mathrm{P}$ concentrations, the experiment would have to be repeated under total darkness.

\section{Materials and Methods}

The experiment and the analyses were performed according to the experimental plan and in accordance with the guidelines and legislation in force, such as the Protection of Animals Act, and the permission for keeping fish under experimental conditions. The study was approved by the 'Landesamt 
für Landwirtschaft, Lebensmittelsicherheit und Fischerei Mecklenburg-Vorpommern-Veterinärdienste und Landwirtschaft' Rostock, Germany with the following ID number: 7221.3-2-022/16.

\subsection{Experimental Design}

The experimental setup consisted of four separate RAS, located at the aquaculture research facilities at the University of Rostock. Each system included three glass aquaria $(100 \mathrm{~cm} \times 40 \mathrm{~cm} \times 50 \mathrm{~cm}$; volume $_{\max }=200 \mathrm{~L}$, volume effective $=150 \mathrm{~L}$ ) and a sump (volume effective $=77 \mathrm{~L}$ ), resulting in a total, effective volume of $527 \mathrm{~L}$ per system. The sump housed a small mechanical filter for the removal of particulate matter (filter pad, $30 \mathrm{ppi}$ ), a moving bed biofilter supporting nitrification (carrier material: HEL-X ${ }^{\circledR}$ Biocarrier, $780 \mathrm{~g}, 836 \mathrm{~m}^{-2} \mathrm{~m}^{-3}, 165 \mathrm{~kg} \mathrm{~m}^{-3} \hat{=} 3.95 \mathrm{~m}^{2}$ effective surface area), a submerged pump (AquaMedic Ocean Runner OR 3500), which was set to a flow rate of $13 \mathrm{~L} \mathrm{~min}^{-1} \hat{=} 4.3 \mathrm{~L} \mathrm{~min}^{-1}$ per aquarium and a heater (GroTech Heater HI-300, $300 \mathrm{~W}$ ). Aeration was achieved with a diaphragm pump (1 RAS ${ }^{-1}$, EHEIM air pump 100), which was connected to one air outlet in each aquarium. Each RAS represented an experimental unit only differing in P concentrations (Section 4.3). All RAS were filled with temperature conditioned tap water.

\subsection{Fish and Feeding}

Each RAS was stocked with juveniles of African catfish $\left(16\right.$ tank $\left.^{-1}\right)$ with a mean weight $( \pm$ SD) of $30.81 \mathrm{~g} \pm 6.56$ (Fischzucht Abtshagen, Abtshagen, Germany). Prior to the start of the experiment, fish were acclimated to the rearing conditions for seven days. A set of 16 animals was stocked in a separate aquarium as a reference for initial fillet and whole-body composition (baseline). This baseline was treated the same way as the control and the test groups during the acclimatization period (first 7 days), held without feeding for two days and was then slaughtered for analysis.

The fish were hand-fed during the whole experiment ( $61 \mathrm{~d}$, from stocking to slaughter), solely with a commercial diet for African catfish (Skretting Meerval START, $3.5 \mathrm{~mm}$ ) at 9:30 am. The feed composition was analyzed with $94.40 \%$ dry matter content, $51.30 \%$ crude protein, $10.80 \%$ fat, $9.85 \%$ ash, $2.03 \%$ fiber, $2.24 \%$ calcium, $0.18 \%$ magnesium, $1.55 \%$ phosphorus, $1.01 \%$ potassium, $0.42 \%$ sodium, and was further specified with $5000 \mathrm{UI} \mathrm{kg}{ }^{-1}$ retinol (E672), $750 \mathrm{UI} \mathrm{kg}^{-1}$ cholecalciferol (E671), $42.0 \mathrm{mg} \mathrm{kg}^{-1}$ iron, $2.1 \mathrm{mg} \mathrm{kg}^{-1}$ iodine, $5.0 \mathrm{mg} \mathrm{kg}^{-1}$ copper, $16.0 \mathrm{mg} \mathrm{kg}^{-1}$ manganese, $110.0 \mathrm{mg} \mathrm{kg}^{-1}$ zinc, $50.0 \mathrm{mg} \mathrm{kg}^{-1}$ ethoxyquin (E324). During acclimatization, all fish were fed $2.0 \%$ of body weight $\mathrm{d}^{-1}$. The feeding was observed to prevent excess feeding and possible leftovers. Uneaten pellets were carefully collected with a small net after $30 \mathrm{~min}$, counted and multiplied with the dry weight of $0.12 \mathrm{~g} \mathrm{pellet}^{-1}$. Due to a good feed intake, the feed ratio was gradually increased to reach a mean daily feeding ratio of $2.64 \% \mathrm{BW} \mathrm{d}^{-1}$. Mortality was determined visually. Dead fish were removed from the tank and the mean calculated weight was used to recalculate the feed ratio per fish tank. Before the fish were slaughtered for the analysis of the initial and final body composition, both the fish of the baseline and the experimental groups were held without feeding for two days.

\subsection{Experimental Units and Water Quality}

The concentrations of $\mathrm{PO}_{4}{ }^{3-}-\mathrm{P}$ were aimed at four levels, with group 1 (control: $\mathrm{P} 0$, without addition of fertilizer): $\mathrm{PO}_{4}{ }^{3-}-\mathrm{P}<10 \mathrm{mg} \mathrm{L}^{-1}$, group 2 (P40): $40 \mathrm{mg} \mathrm{L}^{-1}$, group 3 (P80): $80 \mathrm{mg} \mathrm{L}^{-1}$, and group 4 (P120): $120 \mathrm{mg} \mathrm{L}^{-1}$. P addition was achieved by solving diphosphorus pentoxide $\left(\mathrm{P}_{2} \mathrm{O}_{5}\right.$, Roth, Karlsruhe, Germany) in a mixing tank (HD-polyethylene) in demineralized water. $\mathrm{P}_{2} \mathrm{O}_{5}$ reacts strongly exothermic with water to orthophosphoric acid $\left(\mathrm{P}_{4} \mathrm{O}_{10}+6 \mathrm{H}_{2} \mathrm{O} \rightarrow 4 \mathrm{H}_{3} \mathrm{PO}_{4}\right)$. The acidic solution $(\mathrm{pH}<2)$ was then neutralized with sodium hydroxide $(\mathrm{NaOH}$, Roth, Karlsruhe, Germany) to $\mathrm{pH}$ 6.5-7.0 and left for temperature conditioning overnight. The neutralized, temperature conditioned $\mathrm{PO}_{4}{ }^{3-}$-P solution was then added to the system water into the sump during water exchange. Due to the fact that at neutral to alkaline $\mathrm{pH}$, phosphoric acid precipitates with calcium $\left(3 \mathrm{CaCO}_{3}+2 \mathrm{H}_{3} \mathrm{PO}_{4}=\right.$ $\left.\mathrm{Ca}_{3}\left(\mathrm{PO}_{4}\right)_{2}+3 \mathrm{CO}_{2}+3 \mathrm{H}_{2} \mathrm{O}\right)$ or magnesium $\left(2 \mathrm{H}_{3} \mathrm{PO}_{4}+3 \mathrm{MgCO}_{3} \rightarrow \mathrm{Mg}_{3}\left(\mathrm{PO}_{4}\right)_{2}+3 \mathrm{H}_{2} \mathrm{O}+3 \mathrm{CO}_{2}\right)$, which are dissolved in tap water, the target concentrations were reached after multiple additions of 
neutralized $\mathrm{PO}_{4}{ }^{3-}-\mathrm{P}$ solution during the first week of the experiment. To adjust the conductivity of the four treatment groups, sodium chloride was added to the solutions. The general rearing conditions, defined by the levels of $\mathrm{DO}, \mathrm{pH}$-value, electrical conductivity and redox-potential, were measured in all tanks in triplicate daily between 7:00 and 9:00 a.m. with a multimeter $\left(\mathrm{HACH}^{\circledR}\right.$ Multimeter $\left.\mathrm{HQ} 40 \mathrm{~d}\right)$. To determine the levels of $\mathrm{NH}_{4}{ }^{+}-\mathrm{N}, \mathrm{NO}_{2}{ }^{-}-\mathrm{N}, \mathrm{NO}_{3}{ }^{-}-\mathrm{N}, \mathrm{PO}_{4}{ }^{3-}-\mathrm{P}, \mathrm{K}^{+}, \mathrm{Ca}^{2+}$ and $\mathrm{Mg}^{2+}$, water samples were taken on Mondays, Wednesdays and Fridays at 9:00 am, and were measured colorimetrically with an automated discrete analyzer (ThermoFisher Scientific ${ }^{\mathrm{TM}}$ Gallery ${ }^{\mathrm{TM}}$ ) according to the manufacturer's protocol. To measure the effect of water exchange and $\mathrm{PO}_{4}{ }^{3-}-\mathrm{P}$ dosing to the process water, another water sample was taken $24 \mathrm{~h}$ after water exchange. All samples were measured in triplicates. To maintain an adequate water quality, water exchange of $75 \mathrm{~L} \hat{=} 15 \%$ RAS volume was performed by emptying the pump sumps on Mondays, Wednesdays and Fridays, three hours after feeding.

\subsection{Water Quality Calculations}

Ammonia nitrogen:

$$
c_{i}\left(\mathrm{NH}_{4}^{+}-\mathrm{N}\right)=\frac{c_{i}\left(\mathrm{NH}_{4}^{+}\right)}{\mathrm{M}\left(\mathrm{NH}_{4}^{+}\right)} * \mathrm{M}(\mathrm{N})
$$

with: $c_{i}=$ concentration, $M=$ molar mass, $N=$ nitrogen, $\mathrm{NH}_{4}{ }^{+}=$ammonia.

Total oxidized nitrogen $(T O N)$ :

$$
c_{i}(\mathrm{TON})=\frac{c_{i}\left(\mathrm{TON}, \text { as } \mathrm{NO}_{3}^{-}-\mathrm{N}\right)}{M\left(\mathrm{NO}_{3}^{-}\right)} * M(N)
$$

with $c_{i}=$ concentration, $\mathrm{M}=$ molar mass, $\mathrm{N}=$ nitrogen, $\mathrm{NO}_{3}{ }^{-}=$nitrate, $\mathrm{TON}=$ total oxidized nitrogen .

Nitrite nitrogen:

$$
c_{i}\left(N O_{2}^{-}-N\right)=\frac{c_{i}\left(N O_{2}^{-}\right)}{M\left(N O_{2}^{-}\right)} * M(N)
$$

with $c_{i}=$ concentration, $\mathrm{M}=$ molar mass, $\mathrm{N}=$ nitrogen, $\mathrm{NO}_{2}{ }^{-}=$nitrite.

Nitrate nitrogen:

$$
c_{i}\left(\mathrm{NO}_{3}^{-}-\mathrm{N}\right)=c_{i}(\mathrm{TON})-c_{i}\left(\mathrm{NO}_{2}^{-}-\mathrm{N}\right)
$$

with $c_{i}=$ concentration, $\mathrm{N}=$ nitrogen, $\mathrm{NO}_{2}{ }^{-}=$nitrite, $\mathrm{NO}_{3}{ }^{-}=$nitrate, $\mathrm{TON}=$ total oxidized nitrogen .

Total dissolved nitrogen $(T D N)$ :

$$
c_{i}(T D N)=c_{i} T O N+c_{i}\left(N_{4}^{+}-N\right)
$$

with $c_{i}=$ concentration, $N=$ nitrogen, $T D N=$ total dissolved nitrogen, $T O N=$ total oxidized nitrogen .

Ortho-phosphate phosphorus:

$$
c_{i}\left(\mathrm{PO}_{4}^{3-}-\mathrm{P}\right)=\frac{\left(\mathrm{PO}_{4}^{3-}\right)}{\mathrm{M}\left(\mathrm{PO}_{4}^{3-}\right)} * M(\mathrm{P})
$$

with $c_{i}=$ concentration, $M=$ molar mass, $P=$ phosphorus, $P_{4}{ }^{3-}=$ ortho-phosphate

\subsection{Analysis of Feed and Fish}

To assess the feed composition and the related growth performance of fish as the overall assimilation efficiency of protein, fat and minerals, feed samples were analyzed for $\mathrm{dm}$ content, protein, fat, ash, $\mathrm{Ca}$, total phosphorus (TP), $\mathrm{Na}, \mathrm{Mg}$ and $\mathrm{K}$ at the "Landwirtschaftliche Untersuchungs- und Forschungsanstalt der LMS Agrarberatung GmbH (LUFA) in Rostock, Germany. The feed parameters were measured according to standard methods "VDLUFA", (http:/ / www.vdlufa.de/Methodenbuch/ index.php/de/). Total weight, standard length (nose to base of fin), total length (nose to tip of fin), 
external injuries of all fish were recorded at the beginning and end of the experiment, and skin coloration of all fish was recorded once at the end of the experiment. To determine the skin coloration a numbered grey-chart with nine different shades of grey was used. The fish were placed on the grey chart (RGB codes: 242, 242, 242; 217, 217, 217; 191, 191, 191; 166, 166, 166; 128, 128, 128; 89, 89, 89; 64, 64, $64 ; 38,38,38 ; 13,13,13)$ immediately after catch, and their individual skin coloration was evaluated according to the best match.

The first eight, randomly caught fish (including 3 males and 3 females) from each tank were used for blood withdrawal and dissection. Prior to blood withdrawal, fish were stunned by percussion of the brain, afterwards they were immediately decapitated. To determine the concentrations of functional blood parameters (plasma cortisol, $\mathrm{P}, \mathrm{Ca}^{2+}$ and $\mathrm{NH}_{4}{ }^{+}$cortisol and glucose), approx. $0.5 \mathrm{~mL}$ blood was taken from the Vena caudalis of three males and three females of each tank. The blood glucose was immediately measured (ACCU-CHEK ${ }^{\circledR}$ Aviva) after blood withdrawal. The remaining blood was transferred into heparin-coated tubes (Sarstedt Monovette, Li-Heparin LH, $7.5 \mathrm{~mL}$ ) and stored on ice. Plasma was prepared, and samples were stored at $-20{ }^{\circ} \mathrm{C}$ until analysis of plasma cortisol, $\mathrm{P}, \mathrm{Ca}^{2+}$ and $\mathrm{NH}_{4}{ }^{+}$concentrations. To measure cortisol, an enzyme-linked immunosorbent assay (ELISA) for cortisol in fish $\left(\right.$ Cusabio $\left.^{\circledR}\right)$ with no significant cross-reactivity or interference between fish cortisol and analogues was used according to the manufacturer's protocol. Plasma minerals (inorganic $\mathrm{P}, \mathrm{Ca}^{2+}$, $\mathrm{NH}_{4}^{+}$) were analyzed with commercial assays using Fuji DriChem 4000i (FujiFilm, Minato, Japan).

To determine the fillet and organ indices, the fillets, carcass, gonads, hearts, livers, kidneys and gills were weighed. The morphological analysis of the gills was based on Zayed and Mohamed [69]. To determine negative impact on the gill morphology, samples of the gills were taken at the end of the experiment. From each experimental group, the gill arches from five males and five females $(n=4 \times 10)$ were prepared and documented via photography. The pictures of the gill arches were analyzed to determine potential effects caused by differences of rearing conditions. Also, three samples of gill arches were taken from each group for a microscopic assessment. Therefore, gill lamellae from the second gill arch were collected, left in glycerin and $70 \%$ ethanol for $24 \mathrm{~h}$ at $38{ }^{\circ} \mathrm{C}$, and consequently embedded in paraffin. Glycerin has the same refractive index as cytoplasm, replaces it in the cells, and is therefore useful as mounting medium for light microscopy. Samples of the suprabranchial organ were collected and prepared for microscopic analysis the same way. In case of abnormalities, findings would be compared with the literature.

The fillets of the dissected fish were homogenized three times with a meat mincing machine (BOSCH, MFW 67440) and conveyed for analysis of the same parameters as the feed to the LUFA $\mathrm{GmbH}$ (see above). The remaining eight fish from each tank were analyzed as whole fish, where total weight, standard and total length, skin coloration, sex and external injuries were also recorded. These fish were homogenized and analyzed for whole body composition (LUFA GmbH).

\subsection{Performance Calculations and Definitions}

From the data referring to the fish counting, feed input, weight measurements, TFI, growth (G), FCR, SGR, and organ indices were calculated.

Total feed intake (TFI):

$$
\text { Feed eaten by fish over the experimental period }\left(\mathrm{g}_{\mathrm{fish}}{ }^{-1}\right)
$$

Growth $(\mathrm{G})(\mathrm{g})$ :

$$
\mathrm{G}=W_{t}-W_{0}
$$

with $W_{0}=$ initial fish weight, $W_{t}=$ final fish weight at harvest (last day of experiment).

Feed conversion ratio (FCR):

$$
F C R=\frac{T F I}{W_{t}-W_{0}}
$$

with $T F I=$ total feed intake, $W_{0}=$ initial fish weight, $W_{t}=$ final fish weight. 
Specific growth rate (SGR):

$$
S G R\left[\% d^{-1}\right]=\frac{\left(\operatorname{Ln}\left(W_{t}\right)-\operatorname{Ln}\left(W_{0}\right)\right)}{d} * 100
$$

$W_{0}=$ initial fish weight, $W_{t}=$ final fish weight , and $d=$ days .

Organ index (OI):

$$
O I=\frac{\text { Organ weight }[g]}{\text { Body weight }[g]} * 100
$$

Mortality (Mo):

$$
\text { Mo }[\%]=\frac{\text { Number of dead fish }}{\text { Initial number of fish }} * 100
$$

Apparent Net Nutrient Utilization (ANNU):

$$
A N N U=\frac{\left(W_{t} * X_{t}-W_{0} * X_{0}\right)}{\left(T F I * X_{F}\right)} * 100
$$

$W_{0}=$ initial fish weight, $W_{t}=$ final fish weight, $X_{0}=$ initial nutrient concentration of the fish, $X_{t}=$ final nutrient concentration of the fish, $X_{F}=$ nutrient concentration of the feed.

\subsection{Fish Behavior}

The ethological investigations were based on van de Nieuwegiessen et al. [53]. The behavior was observed in individual animals, as well as in the whole group after the third and fifth week of the experiment. Observation of an individual was as follows: in each tank, one animal was observed for five minutes. Behavioral patterns such as swimming, air breathing and agonistic behavior were quantitatively documented. The ethogram is given in Table 7.

Table 7. Ethogram—-behavioral patterns and their definition, adapted from van de Nieuwegiessen et al. [53].

\begin{tabular}{cc}
\hline Behavior & Definition \\
\hline $\begin{array}{c}\text { Agonistic behavior } \\
\text { Air breathing }\end{array}$ & $\begin{array}{c}\text { Chasing or biting a fish, or being chased upon or bitten by another fish } \\
\text { The animal moves to the water surface and takes a gulp of air. This was checked by } \\
\text { Swimming }\end{array}$ \\
\hline
\end{tabular}

In case the investigated fish got out of sight during observation, another fish was followed, starting from the position the former was lost and the observation continued according to van de Nieuwegiessen et al. [53]. The group behavior was determined by evaluation of video recordings (from outside the tanks) of five minutes. Thereby, the number of swimming fish was determined in $30 \mathrm{~s}$ intervals. The activity pattern was calculated as percentage of swimming in comparison to the total number of fishes. Air breathing and agonistic behavior were documented as frequency.

\subsection{Data Analyses}

Data analyses were performed with SPSS (IBM ${ }^{\circledR}$ SPSS $^{\circledR}$ Statistics Version 22). All data were tested for normal distribution using the Shapiro-Wilk test. When data showed normal distribution, One-Way-ANOVA was performed and homogeneity of variance was tested using the Levene's test: concentrations of $\mathrm{Ca}^{2+}$ in the rearing water, initial body weight, whole body contents of ash, protein, fat, $\mathrm{Ca}, \mathrm{P}, \mathrm{Na}$ and $\mathrm{K}$, fat content in fillet, ANNUs of protein, fat, $\mathrm{P}, \mathrm{Mg}$ and $\mathrm{K}$, heart index, blood glucose, swimming activity (individual), agonistic behavior (individual), air breathing (group).

When data were not normally distributed, the Kruskal-Wallis test was performed: levels of DO, temperature, $\mathrm{pH}$-value, salinity, conductivity, redox-potential and concentrations of $\mathrm{NH}_{4}{ }^{+}-\mathrm{N}, \mathrm{NO}_{2}{ }^{-}-\mathrm{N}$, $\mathrm{TON}, \mathrm{NO}_{3}{ }^{-}-\mathrm{N}, \mathrm{TDN}, \mathrm{PO}_{4}{ }^{3-}-\mathrm{P}, \mathrm{K}^{+}, \mathrm{Mg}^{2+}$ in the rearing water, whole body contents of $\mathrm{dm}$ and $\mathrm{Mg}$, fillet 
contents of dm, ash, protein, $\mathrm{Ca}, \mathrm{P}, \mathrm{Mg}$, $\mathrm{Na}$ and $\mathrm{K}$, ANNUs of $\mathrm{Ca}$ and $\mathrm{Na}$, skin darkness, serum cortisol, biting wounds, swimming activity (group), agonistic behavior (group), air breathing (individual). When One-Way-ANOVA showed significant differences and data showed homogeneity of variances Tukey-HSD (Honestly Significant Difference) was used as post-test (initial body weight, fat content in fillet), when data showed no homogeneity of variances Dunnett-T3 was used as post-hoc-tests (air breathing group).

Plasma $\mathrm{P}, \mathrm{Ca}, \mathrm{NH}_{3}$ were analyzed via variance analyses (PROC MIXED; SAS version 9.4; SAS Institute, Cary, NC, USA), including effects represented by treatment, tank and sex. Body weight related traits (total length, standard length, fillet ratio, SGR, FCR, TFI) were corrected for initial live weight (mean per tank) used as co-variable. The level of significance was set at $p<0.05$.

\section{Conclusions}

Economical, ecological and ethical considerations require healthy animals with high feed efficiency in aquaculture production. Modern integrated systems such as aquaponics demand adjustment of water parameters in order to improve plant production, however, with no negative consequences on fish growth, welfare and product quality. This study demonstrates that different $\mathrm{PO}_{4}{ }^{3-}-\mathrm{P}$ levels between 3.6 and $120 \mathrm{mg} \mathrm{L}^{-1}$ do not affect the P contents of $1 \%$ inside the fillet of African catfish. However, the fat content significantly increases with increasing $\mathrm{PO}_{4}{ }^{3-}-\mathrm{P}$, with relevance for product quality. The near absence of $\mathrm{PO}_{4}{ }^{3-}-\mathrm{P}$ inside the water, combined with the absence of sediments as $\mathrm{P}$ deposits, results in a trend of reduced growth, indicating the importance of dissolved or precipitated $\mathrm{P}$ availability inside the system even under the use of commercial diets. Elevated levels of $\mathrm{PO}_{4}{ }^{3-}-\mathrm{P}$ up to $80 \mathrm{mg} \mathrm{L}^{-1}$ inside the rearing water did not negatively affect the fish, with best growth performance under $40-80 \mathrm{mg} \mathrm{L}^{-1} \mathrm{PO}_{4}{ }^{3-}$-P. Only highly elevated $\mathrm{PO}_{4}{ }^{3-}$-P levels of $120 \mathrm{mg} \mathrm{L}^{-1}$ significantly reduce the welfare status. This suggests that limited addition of $\mathrm{PO}_{4}{ }^{3-}-\mathrm{P}$ fertilizer to the plant units in coupled aquaponics with African catfish and the reuse of the plant water in the recirculation aquaculture system are beneficial for both the plants and the fish.

Author Contributions: S.M.S.: Experimental planning, main writing, fish performance; A.A.B.: Fish physiology; J.B.: Main sampling, writing; B.B.: Fish welfare; M.O.: Statistical analysis, blood metabolites; B.W.: Product quality; H.W.P.: Experimental planning, writing.

Funding: This study was financially supported by the Ministry of Agriculture, Environment and Consumer Protection of Mecklenburg Western Pomerania (BNRZD: 13903000 0103) and EIP-AGRI operational groups (WM-EIP-0007-1 5), and the Leibniz Science Campus Phosphorus Research Rostock (SAS-2015-IOW-LWC). We thank the Editors and the reviewers of this paper for their constructive feedback.

Conflicts of Interest: The authors declare no conflict of interests.

\section{References}

1. Becquer, A.; Trap, J.; Irshad, U.; Ali, M.A.; Claude, P. From soil to plant, the journey of P through trophic relationships and ectomycorrhizal association. Front. Plant Sci. 2014, 5, 548. [CrossRef] [PubMed]

2. Guillaume, J.; Kaushik, S.; Bergot, P.; Métailler, R. Nutrition and Feeding of Fish and Crustaceans; Springer Science \& Business Media: Chichester, UK, 2001; ISBN 1-85233-241-7.

3. Halver, J.E.; Hardy, R.W. (Eds.) Fish Nutrition, 3rd ed.; Elsevier: Seattle, WA, USA, 2002; ISBN 978-0-12-319652-1.

4. Antony Jesu Prabhu, P.; Schrama, J.W.; Kaushik, S.J. Quantifying dietary phosphorus requirement of fish-a meta-analytic approach. Aquac. Nutr. 2013, 19, 233-249. [CrossRef]

5. Jones, J.B., Jr. Hydroponics: Its history and use in plant nutrition studies. J. Plant Nutr. 1982, 5, $1003-1030$. [CrossRef]

6. Resh, H.M. Hydroponic Food Production: A Definite Guidebook for the Advanced Home Gardener and the Commercial Hydroponic Grower, 7th ed.; CRC Press: Boca Raton, FL, USA, 2013; ISBN 978-1-43-987867-5.

7. Palm, H.W.; Knaus, U.; Appelbaum, S.; Goddek, S.; Strauch, S.M.; Vermeulen, T.; Jijakli, M.H.; Kotzen, B. Towards commercial aquaponics: A review of systems, designs, scales and nomenclature. Aquac. Int. 2018, 26, 318-342. [CrossRef] 
8. Somerville, C.; Cohen, M.; Pantanella, E.; Stankus, A. Small scale aquaponic food production. FAO Fish. Aquac. Tech. Pap. 2014, 589, 11-181.

9. Graber, A.; Junge, R. Aquaponic Systems: Nutrient recycling from fish wastewater by vegetable production. Desalination 2009, 246, 147-156. [CrossRef]

10. Suhl, J.; Dannehl, D.; Kloas, W.; Baganz, D.; Jobs, S.; Scheibe, G.; Schmidt, U. Advanced aquaponics: Evaluation of intensive tomato production in aquaponics vs. conventional hydroponics. Agric. Water Manag. 2016, 178, 335-344. [CrossRef]

11. Strauch, S.M.; Wenzel, L.C.; Bischoff, A.; Dellwig, O.; Klein, J.; Schüch, A.; Wasenitz, B.; Palm, H.W. Commercial African catfish (Clarias gariepinus) recirculating aquaculture systems: Assessment of element and energy pathways with special focus on the phosphorus cycle. Sustainability 2018, 10, 1805. [CrossRef]

12. Goddek, S.; Delaide, B.; Mankasingh, U.; Ragnarsdottir, K.V.; Jijakli, H.; Thorarinsdottir, R. Challenges of sustainable and commercial aquaponics. Sustainability 2015, 7, 4199-4224. [CrossRef]

13. Kloas, W.; Groß, R.; Baganz, D.; Graupner, J.; Monsees, H.; Schmidt, U.; Staaks, G.; Suhl, J.; Tschirner, M.; Wittstock, B.; et al. A new concept for aquaponic systems to improve sustainability, increase productivity, and reduce environmental impacts. Aquac. Environ. Interact 2015, 7, 179-192. [CrossRef]

14. Razzaque, M.S. Phosphate toxicity: New insights into an old problem. Clin. Sci. 2011, 120, 91-97. [CrossRef]

15. Ye, C.X.; Liu, Y.J.; Tian, L.X.; Mai, K.S.; Du, Z.Y.; Yang, H.J.; Niu, J. Effect of dietary calcium and phosphorus on growth, feed efficiency, mineral content and body composition of juvenile grouper, Epinephelus coioides. Aquaculture 2006, 255, 263-271. [CrossRef]

16. Oliva-Teles, A.; Pimentel-Rodrigues, A. Phosphorus requirement of European sea bass (Dicentrarchus labrax L.) juveniles. Aquac. Res. 2004, 35, 636-642. [CrossRef]

17. Yang, S.D.; Lin, T.S.; Liu, F.G.; Liou, C.H. Influence of dietary phosphorus levels on growth, metabolic response and body composition of juvenile silver perch (Bidyanus bidyanus). Aquaculture 2006, 253, 592-601. [CrossRef]

18. Ufodike, E.B.C.; Onusiriuka, B.C. Acute toxicity of inorganic fertilizers to African catfish, Clarias gariepinus (Teugals). Aquac. Res. 1990, 21, 181-186. [CrossRef]

19. van Bussel, C.G.J.; Mahlmann, L.; Kroeckel, S.; Schroeder, J.P.; Schulz, C. The effect of high ortho-phosphate water levels on growth, feed intake, nutrient utilization and health status of juvenile turbot (Psetta maxima) reared in intensive recirculating aquaculture systems (RAS). Aquac. Eng. 2013, 57, 63-70. [CrossRef]

20. Palm, H.W.; Knaus, U.; Wasenitz, B.; Bischoff, A.A.; Strauch, S.M. Proportional up scaling of African catfish (Clarias gariepinus Burchell, 1822) commercial recirculating aquaculture systems disproportionally affects nutrient dynamics. Aquaculture 2018, 491, 155-168. [CrossRef]

21. Trejo-Téllez, L.I.; Gómez-Merino, F.C. Nutrient solutions for hydroponic systems. In Hydroponics- $A$ Standard Methodology for Plant Biological Researches; Asao, T., Ed.; InTechOpen: London, UK, 2012; pp. 1-22, ISBN 9789535103868.

22. Dorozhkin, S.V. A detailed history of calcium orthophosphates from 1770s till 1950. Mater. Sci. Eng. C Mater. Biol. Appl. 2013, 33, 3085-3110. [CrossRef] [PubMed]

23. van Rijn, J. Waste treatment in recirculating aquaculture systems. Aquac. Eng. 2013, 53, 49-56. [CrossRef]

24. Oellermann, L.K. A Comparison of the Aquaculture Potential of Clarias gariepinus (Burchell, 1822) and Its Hybrid with Heterobranchus longifilis Valenciennes, 1840 in Southern Africa. Ph.D. Thesis, Rhodes University, Grahamstown, South Africa, 1995.

25. Schram, E.; Roques, J.A.C.; Abbink, W.; Spanings, T.; de Vries, P.; Bierman, S.; van de Vis, H.; Flik, G. The impact of elevated water ammonia concentration on physiology, growth and feed intake of African catfish (Clarias gariepinus). Aquaculture 2010, 306, 108-115. [CrossRef]

26. Roques, J.A.; Schram, E.; Spanings, T.; Schaik, T.; Abbink, W.; Boerrigter, J.; de Vries, P.; van de Vis, G.; Flik, G. The impact of elevated water nitrite concentration on physiology, growth and feed intake of African catfish Clarias gariepinus (Burchell 1822). Aquac. Res. 2015, 46, 1384-1395. [CrossRef]

27. Schram, E.; Roques, J.A.C.; Abbink, W.; Yokohama, Y.; Spanings, T.; Vries, P.; Biermann, S.; van de Vis, H.; Flik, G. The impact of elevated water nitrate concentration on physiology, growth and feed intake of African catfish Clarias gariepinus (Burchell 1822). Aquac. Res. 2014, 45, 1499-1511. [CrossRef]

28. Hogendoorn, H.; Jansen, J.A.J.; Koops, W.J.; Machiels, M.A.M.; van Ewijk, P.H.; van Hees, J.P. Growth and production of the African catfish, Clarias lazera (C. \& V.): II. Effects of body weight, temperature and feeding level in intensive tank culture. Aquaculture 1983, 34, 265-285. [CrossRef] 
29. Eding, E.H.; Janssen, K.; Heinsbroek, L.T.N.; Verreth, J.A.J.; Schrama, J.W. Can water phosphorus level in recirculating aquaculture systems (RAS) compensate for low dietary phosphorus level in Nile tilapia Oreochromis niloticus? In Proceedings of the 9th International Conference on Recirculating Aquaculture, Roanoke, VA, USA, 24-26 August 2012.

30. Hoffman, L.C.; Prinsloo, J.F.; Theron, J.; Casey, N.H. The genotypic influence of four strains of Clarias gariepinus on the larvae body proximate, total lipid fatty acid, amino acid and mineral compositions. Comp. Biochem. Physiol. B Biochem. Mol. Biol. 1995, 110, 589-597. [CrossRef]

31. Toko, I.I.; Fiogbe, E.D.; Kestemont, P. Mineral status of African catfish (Clarias gariepinus) fed diets containing graded levels of soybean or cottonseed meals. Aquaculture 2008, 275, 298-305. [CrossRef]

32. Fawole, O.O.; Ogundiran, M.A.; Ayandiran, T.A.; Olagunju, O.F. Proximate and mineral composition in some selected fresh water fishes in Nigeria. Int. J. Food Saf. 2007, 9, 52-55.

33. Wedekind, H. Dietary influences on product quality in African catfish (Clarias gariepinus). J. Appl. Ichthyol. 1995, 11, 347-353. [CrossRef]

34. Rosa, R.; Bandarra, N.M.; Nunes, M.L. Nutritional quality of African catfish Clarias gariepinus (Burchell 1822): A positive criterion for the future development of the European production of Siluroidei. Int. J. Food Sci. Technol. 2007, 42, 342-351. [CrossRef]

35. Adewumi, A.A.; Adewole, H.A.; Olaleye, V.F. Proximate and elemental composition of the fillets of some fish species in Osinmo Reservoir, Nigeria. ABJNA 2014, 5, 109-117. [CrossRef]

36. Wasenitz, B.; Karl, H.; Palm, H.W. Composition and quality attributes of fillets from different catfish species on the German market. J. Food Saf. Food Qual. 2018, 69, 57-65.

37. van Dam, A.A.; Pauly, D. Simulation of the effects of oxygen on food consumption and growth of Nile tilapia, Oreochromis niloticus (L.). Aquac. Res. 1995, 26, 427-440. [CrossRef]

38. Kaushik, S.J.; Doudet, T.; Médale, F.; Aguirre, P.; Blanc, D. Protein and energy needs for maintenance and growth of Nile tilapia (Oreochromis niloticus). J. Appl. Ichthyol. 1995, 11, 290-296. [CrossRef]

39. Kaushik, S.J.; Médale, F. Energy requirements, utilization and dietary supply to salmonids. Aquaculture 1994, 124, 81-97. [CrossRef]

40. Dersjant-Li, Y. Impact of Dietary Cation Anion Difference in Fish and Pigs: A Comparative Study. Ph.D. Thesis, Wageningen University, Wageningen, The Netherlands, 2000.

41. Al-Kholy, A.; Ishak, M.M.; Youssef, Y.A.; Khalil, S.R. Phosphorus uptake from water by Tilapia zillii (Gervais). Hydrobiologia 1970, 36, 471-478. [CrossRef]

42. Sugiura, S.H.; McDaniel, N.K.; Ferraris, R.P. In vivo fractional Pi absorption and NaPi-II mRNA expression in rainbow trout are upregulated by dietary P restriction. Am. J. Physiol. Regul. Integr. Comp. Physiol. 2003, 285, 770-781. [CrossRef] [PubMed]

43. Sugiura, S.H.; Ferraris, R.P. Dietary phosphorus-responsive genes in the intestine, pyloric ceca, and kidney of rainbow trout. Am. J. Physiol. Regul. Integr. Comp. Physiol. 2004, 287, 541-550. [CrossRef] [PubMed]

44. Woo, P.T.K.; Bruno, D.W. (Eds.) Fish Diseases and Disorders, 2nd ed.; CABI: Wallingford, UK, 2011; Volume 3, ISBN 978-1-84-593554-2.

45. Robinson, E.H.; Jackson, L.S.; Li, M.H. Supplemental phosphorus in practical channel catfish diets. J. World Aquac. Soc. 1996, 27, 303-308. [CrossRef]

46. Oster, M.; Just, F.; Büsing, K.; Wolf, P.; Polley, C.; Vollmar, B.; Muráni, E.; Ponsuksili, S.; Wimmers, K. Toward improved phosphorus efficiency in monogastrics-Interplay of serum, minerals, bone, and immune system after divergent dietary phosphorus supply in swine. Am. J. Physiol. Regul. Integr. Comp. Physiol. 2016, 310, 917-925. [CrossRef]

47. Oster, M.; Gerlinger, C.; Heide, K.; Just, F.; Borgelt, L.; Wolf, P.; Polley, C.; Vollmar, B.; Muráni, E.; Ponsuksili, S.; et al. Lower dietary phosphorus supply in pigs match both animal welfare aspects and resource efficiency. Ambio 2018, 47, 20-29. [CrossRef]

48. Ip, Y.K.; Chew, S.F.; Wilson, J.M.; Randall, D.J. Defences against ammonia toxicity in tropical air-breathing fishes exposed to high concentrations of environmental ammonia: A review. J. Comp. Physiol. B 2004, 174, 565-575. [CrossRef]

49. Ellis, T.; Yildiz, H.Y.; López-Olmeda, J.; Spedicato, M.T.; Tort, L.; Øverli, Ø.; Martins, C.I. Cortisol and finfish welfare. Fish Physiol. Biochem. 2012, 38, 163-188. [CrossRef] [PubMed]

50. Losordo, T.M.; Masser, M.P.; Rakocy, J. Recirculating aquaculture tank production systems. SRAC 2000, 454, $1-16$. 
51. Hargreaves, J.A.; Tucker, C.S. Managing ammonia in fish ponds. Stoneville. SRAC 2004, 4603, 1-8.

52. Rakocy, J.E.; Masser, M.P.; Losordo, T.M. Recirculating aquaculture tank production systems: Aquaponics-Integrating fish and plant culture. SRAC 2006, 454, 1-16.

53. van de Nieuwegiessen, P.G.; Olwo, J.; Khong, S.; Verreth, J.A.J.; Schrama, J.W. Effects of age and stocking density on the welfare of African catfish, Clarias gariepinus Burchell. Aquaculture 2009, 288, 69-75. [CrossRef]

54. Hontela, A.; Rasmussen, J.B.; Audet, C.; Chevalier, G. Impaired cortisol stress response in fish from environments polluted by PAHs, PCBs, and mercury. Arch. Environ. Contam. Toxicol. 1992, 22, 278-283. [CrossRef]

55. Fujii, R.; Miyashita, Y. Receptor mechanisms in fish chromatophores-V. MSH disperses melanosomes in both dermal and epidermal melanophores of a catfish (Parasilurus asotus). Comp. Biochem. Physiol. C Comp. Pharmacol. Toxicol. 1982, 71, 1-6. [CrossRef]

56. Sugimoto, M. Morphological color changes in fish: Regulation of pigment cell density and morphology. Microsc. Res. Tech. 2002, 58, 496-503. [CrossRef]

57. Osborn, C.M. The role of the melanophore-dispersing hormone of the pituitary in the color changes of the catfish. Proc. Natl. Acad. Sci. USA 1938, 24, 121-125. [CrossRef]

58. Mustapha, M.; Okafor, B.; Olaoti, K.; Oyelakin, O. Effects of three different photoperiods on the growth and body coloration of juvenile African catfish, Clarias gariepinus (Burchell). Arch. Pol. Fish. 2012, 20, 55-59. [CrossRef]

59. Holmberg, K. Ultrastructure and response to background illumination of the melanophores of the Atlantic hagfish, Myxine glutinosa, L. Gen. Comp. Endocrinol. 1968, 10, 421-428. [CrossRef]

60. Dong, X.L.; Lei, W.; Zhu, X.M.; Han, D.; Yang, Y.X.; Xie, S.Q. Effects of dietary oxidized fish oil on growth performance and skin colour of Chinese longsnout catfish (Leiocassis longirostris Günther). Aquac. Nutr. 2011, 17, 861-868. [CrossRef]

61. Agius, C.; Roberts, R.J. Melano-macrophage centres and their role in fish pathology. J. Fish Dis. 2003, 26, 499-509. [CrossRef]

62. Shao, Q.; Ma, J.; Xu, Z.; Hu, W.; Xu, J.; Xie, S. Dietary phosphorus requirement of juvenile black seabream, Sparus macrocephalus. Aquaculture 2008, 277, 92-100. [CrossRef]

63. Hepher, B. Nutrition of Pond Fishes, 1st ed.; Press Syndicate of the University of Cambridge: Cambridge, UK, 1988; ISBN 0521341507.

64. Hosoya, S.; Johnson, S.C.; Iwama, G.K.; Gamperl, A.K.; Afonso, L.O.B. Changes in free and total plasma cortisol levels in juvenile haddock (Melanogrammus aeglefinus) exposed to long-term handling stress. Comp. Biochem. Physiol. A Mol. Integr. Physiol. 2007, 146, 78-86. [CrossRef] [PubMed]

65. Baßmann, B.; Brenner, M.; Palm, H.W. Stress and Welfare of African Catfish (Clarias gariepinus Burchell, 1822) in a Coupled Aquaponic System. Water 2017, 9, 504. [CrossRef]

66. Hecht, T.; Uys, W.; Britz, P.J. The culture of Sharptooth Catfish, Clarias gariepinus in Southern Africa. S. Afr. Natl. Sci. Program. Rep. 1988, 153, 47-61.

67. Belão, T.C.; Leite, C.A.C.; Florindo, L.H.; Kalinin, A.L.; Rantin, F.T. Cardiorespiratory responses to hypoxia in the African catfish, Clarias gariepinus (Burchell 1822), an air-breathing fish. J. Comp. Physiol. B 2011, 181, 905. [CrossRef]

68. Britz, P.J.; Pienaar, A.G. Laboratory experiments on the effect of light and cover on the behaviour and growth of African catfish, Clarias gariepinus (Pisces: Clariidae). J. Zool. 1992, 227, 43-62. [CrossRef]

69. Zayed, A.E.; Mohamed, S.A. Morphological study on the gills of two species of fresh water fishes: Oreochromis niloticus and Clarias gariepinus. Ann. Anat. 2004, 186, 295-304. [CrossRef]

(c) 2019 by the authors. Licensee MDPI, Basel, Switzerland. This article is an open access article distributed under the terms and conditions of the Creative Commons Attribution (CC BY) license (http://creativecommons.org/licenses/by/4.0/). 